\title{
Romania: \\ The role of Roma women \\ in intra-community conflict management
}

\author{
Ciprian SANDU
}

\begin{abstract}
The following article argues that, despite the traditional challenges Roma women faced, they are able to contribute significantly to the resolution of intra-community conflicts and earned, in time, a position of respect for this reason. Major barriers remain, but, in the same time, the evolution of the community is starting to give the Roma women empowerment over the conflict resolution mechanisms.
\end{abstract}

Keywords: Kris, women, conflict management, gossip, curse, oath, tradition.

The following article is part of a personal research inside the Roma Kalderash community in Romania, specifically in two areas of the country. The aim of the research was to find out and analyze the mechanisms used by this remote community for the intra-community conflicts. Besides the fact that the research found out that this community has its own way of dealing conflicts, other than the formal justice, it showed that the Roma women have their specific place inside this mechanisms and the following pages will discuss about the Roma women as conflict managers.

After hundreds of hours of interaction with the Roma community from Vâlcea and Gorj, we have come to the conclusion that it is very difficult to give a correct and unitary definition of what traditional Roma mean. The reason is partly due to self-isolation from the rest of the society and the stereotypes of the majority of the society. In some places we find them defined by their Indian origin, sometimes by the trades practiced

\author{
Ciprian SANDU \\ Researcher, Conflict Studies Center, \\ Cluj-Napoca, Romania \\ E-mail: ciprian.sandu@fspac.ro \\ Conflict Studies Quarterly \\ Issue 31, April 2020, pp. 56-63 \\ DOI:10.24193/csq.31.4 \\ Published First Online: 05/04/2020
}


and, unfortunately, very often by the negative mass-media titles. Moreover, beyond the historical theories and the traditional trades, their personal way of self-identification makes it very difficult to define them by an outsider.

As mentioned above, I searched a lot for a definition of traditional Roma and I found one that would serve the purpose of this research. In my opinion, traditional Roma are those who define themselves as Roma who still respect the moral code of the community, who have a preference for a (semi)nomadic lifestyle or have had such a lifestyle, but they have stopped to travel, either temporarily or permanently, for various reasons (legislation, age or health status).

Of all the Roma nations, for the purpose of this research, I chose to focus on the group of Kalderash. The main reason for this decision is that they still maintain the rules and customs specific to the traditional lifestyle, being recognized by the rest of the Roma (but also by the rest of the society) as the most traditional Roma today, the only ones who still respect the "traditions and values of the community". In the following, I will give a brief presentation of the Kalderash Roma.

The Roma Kalderash are spread especially in the area of Oltenia, especially in the counties of Valcea, Dolj, Olt, Gorj and Mehedinţi. Important groups can also be found in Transilvania but Oltenia is recognized as the area that encompasses most of this subgroup. The name of this group comes from its basic task, the manufacture of boilers. They also spoil these boilers with mower. They also make household goods from aluminum, which they sell through markets or fairs.

As with other Roma groups, the family occupies a special place. The bigger it is, the more it is respected. The head of the family is the man, being responsible for the financial part, while the woman is responsible for the domestic affairs. Regarding the education of the children, each parent is responsible for the education of the same-sex children. The mother teaches the girls the skills necessary for household chores (sewing, washing, cooking), and the boys learn how to make boilers as well as how to be the future head of the family. Being responsible for the education of the children, from childhood until marriage, she has an important educational role to ensure the survival of the group. For this reason, the woman is the conservative element in the social group because she is able to make the traditions reproduce but, at the same time, it can itself be an element of change. As far as the home is concerned, the Kalderash kept their nomadic lifestyle. It should be mentioned here that, although they still declare themselves nomads, we are actually talking about a semi-nomadic lifestyle, characterized more by its economic side and less by tradition.

Being a traditional Roma sub-group, the Kaderash community is a patriarchal one. Due to this, women are often powerless to prevent conflicts, they are excluded from the negotiating tables when it comes to their resolution and marginalized in the post- 
conflict reconstruction and reconciliation efforts. More specifically, they are excluded from formal decision-making processes.

This situation is not an isolated one. For example, Bangalie (2011) present the situation of women in Sierra Leone before and after the civil war, arguing that their role changed from not being a part of the decision-making process to a position of respect. Achieng (2015) argues that the Kenyan government failed to address the role of women in conflict management, even if they are directly involved in the conflict. As the case in Sierra Leone, Achieng argues that the inclusion of women in the decision-making process, especially regarding conflicts, increases their efficiency. A conference report of the Woodrow Wilson International Center for Scholars and Women Waging Peace (2002) present the situation of women in Asia, Central America and Africa in the same light like the above mentioned authors, mentioning that women can help a lot the resolution of conflicts both in large-scale conflicts (war) or small-scale ones (community or family conflicts). Closely related with the present study is the study of Ragandang and Ponce (2019) regarding the role of bae (women members of the tribal council) in the Philippines traditional system of conflict resolution despite the patriarchal nature of the tribes.

The Kalderash Roma community has its own way of dealing internal conflicts. Based on the community's code of conduct, Romanipen, it is based around the notion of honor and shame. Being a very close community, its members having strong ties, the conflict resolution process involves everyone. One of the most known practices is the Kris (or Kris Romani), meaning judgment.

One dimension of this court of traditional Roma is the role of gender. Until 20-30 years ago, women played a minor, almost insignificant role. More concretely, being a strongly patriarchal community, Roma women could not claim the Kris, regardless of the severity of the cause or the damage/injury. Their families were responsible for seeking judgment. In this situation, the main role was played by the husband, who was the one who went in front of the community and requested the judgment on behalf of the wife. The reason behind this is the fact that, according to the Roma rules, the man is a supporter and defender of the prestige of the family, he acts in the public space and is responsible for the interaction with the outside world. He is also the head of the family and, in this capacity, only he has the authority and decision-making power. More specifically, the husband is the one who runs the family and he is held responsible for all the problems caused in the family. Having such a big responsibility, he has full power of decision over his wife and children. If the request was accepted, the wife played a secondary role, accompanying her husband in the hearings stage and intervening only if the judges requested it. If the woman was a widow, her father played the main role, this being the one who would have seek judgment. In the situation in which she also fathered, the girl's uncle was the one with this responsibility, followed by her brothers. 
Let me tell you how it is, I am old and I know what I say ... the man is the head, he decides, this is how it used to be. In court, we were not allowed, now from the Revolution, things have changed. If anything, you went home to the man, you told him what happened to you and he decided, he would go to them and settle the problem directly or go to the judges. Whatever he did, we weren't allowed to go because this is the law, it's up to the men. Further to the Revolution, it was a little easier for the judges to call us, and then to intervene to convince men that I do not know what, but they do the law, it is up to the man, we are with the children, with the house, we don't really get into it (personal communication, Kalderash woman, 14.06.2017).

In recent years, women have been allowed to participate more actively at the Kris. More, according to one of the interviewed Roma judges, they played an important role in facilitating the agreement. According to him, it is well known that "Roma women are like fire" and can influence their husbands to accept the verdict given after the Kris or the offer of the other party. For this reason, in many cases, judges rely on the wives of the parties to the dispute to facilitate an agreement or to ensure that they accept and respect the verdict:

Oh, that there have been cases when women are more involved than the men, there are also cases when in a clan, in a family, I smell, I feel like a judge and I see who is more influential in the family, I get in touch with the woman to help me because I know it's hell in it and can tell a man "Come on, Roma! Let's make peace!" and what the woman says I know the man listens to (personal communication, krisinitor, Tg. Jiu, 06.09.2017).

Moreover, although the traditional Roma community remains a patriarchal one, women also play an important role in Kris Romani, with some women becoming even judges, with the risk of provoking controversy and opposition from more conservative members:

Oh, God, we made a judges organization, set up about 7-8 years ago and I told them so, if you go with tradition you will be great. There was a meeting in Bucharest from all the counties, and when I saw that women were in the status, I took and left, and I told the organizer Where have you ever seen a woman judge, to be a judge? The biggest shame for a judge is when you say what judges you are, women judge better than you, a big shame, there is no such thing as women being judges (personal communication, krisinitor, 06.09.2017).

The Roma woman has also a mystical role inside the community and its conflict resolution methods. More specifically, if the community is not satisfied with the Kris verdict (the reasons may be different, the community knows that the parties are lying or the judges are corrupt, the Kris procedures are not respected and the verdict is delayed), an 
old woman can deflect the judgment by "raising her dress in the head ". Such situations derive from two things. First of all, in the tradition of the community according to which the elderly woman is responsible for the curse of anybody, being endowed with this ability, she acquires a very important status as advisor and possessor of many magical, premonitory, reparative and protective values (Grigore, 2008, pp. 79-80). Moreover, older women enjoy the respect of the whole community, an example being that they can smoke in front of men, which is completely forbidden to younger women. Secondly, this ritual is based on the principle of impurity in Romanipen. By showing the lower part of the body (or just simulating this by raising a corner of the skirt), the part considered dirty or impure (maximally), the woman in question transfers this impurity to the entire assembly, the dirt actually meaning contempt and mockery of the community. As a short parenthesis, according to the Roman faith, if a woman passes in front of a man, he will become dirty and unlucky. In conclusion, the judgment (the verdict) is annulled and the one who requested the trial is required to request a new Kris with other judges:

Only once did it happen, but my great-grandfather used to tell us that it happened quite often ... I was judging some powerful people, no matter why, I gave the verdict, it were five of us, we all thought and judged the same, they didn't agreed and they brought a woman from them, an old woman, and we explained where and how and we see the woman take her skirts and pick them up and pretend we want to hurt the family ... said in our grace look here, judge the bastards again ... and she's gone. I was right, I told you, we were five and we all took the verdict, but we had to close the trial and we left and we left the parties to find someone else because we couldn't anymore (personal communication, krisinitor, Tg. Jiu, 06.12.2017).

At the heart of Kris's proceedings, from the beginning to the end, is the oath (solax) that the parties and witnesses must take before, during and / or at the end of the trial. Performed in front of the audience, this is a sacred character for the Roma community and has the role of confirming the statements made because, as one of the participants in this study tells us, the gypsies who swore must always tell the truth, because the oath is holy. Due to the fact that the Roma women have mystical powers, the oath is made in the presence of a woman, specifically an elderly one, so that she can curse the one who take the oath in order to prevent a false one.

The need for the oath arises when the judges consider that the statements of the parties are contradictory or there is a suspicion that they lie or hide the truth (lie by omission). In this way, the oath has the role of forcing the Romani Kalderash not to lie because, in their opinion, a crooked oath has only two results, both negative - either a curse that affects the luck and the health of the person concerned, or the shame of it and the whole its families because that is considered maxrime (dirty). More concretely, if a Roma takes a vow and lies or does not respect his oath, the community will punish 
him by marginalization and even denigration, both because of the lies and the curse that can affect the entire community.

Over time we have heard a lot of curses and we are afraid of them, we are afraid ... we have all kinds of ways, may the Devil find you; may God beat you; not to be lucky in life, snakes will eat you ... you know. We are afraid because if he swears badly or the curse is thrown, the sin falls on children, grandchildren and the worst thing for gypsies is the disease of children, ie epilepsy. And it is said that the curse will fall on the children or the one who swore badly and will get sick with epilepsy, and many are scared of this thing, better acknowledge, pay financially (interview, krisinitor, Tg. Jiu, 06.12.2017).

Coming from the same archaic background as the oaths, the curse (arman) can be considered a form of social control or a method of making the culprit to acknowledge their guilt. As with oaths, curses contain references to things important to the Kalderash community, such as divinity, good fortune or family. According to our sources, the cursed person is considered exposed to a major and permanent evil, both he and his family and, in conclusion, will recognize or tell the truth so that the curse thrown away will no longer have any effect. In this case, as in the case of oaths, the superstitions and beliefs of the community function as a factor of intimidation and prevention of possible deviations or false testimonies. As with the oaths, it's the job of the women to throw the curse on someone because they are the only one who have the mystical powers inside the community.

Gossip is another strategy used by the members of the community to informally manage deviant behavior:

... when there is a conflict, the women come out first and that one screams at that, that one screams at the other, from both sides and then the community is informed and they have to remove the respective shame, that is to make gypsy fund to it turns out that what is said and heard by the community must highlight the shame ... to prove.... a suspicion that is or is shouting ... many times the parties that came to trial were not guilty, but if two women were disputed, that one shouted at her, the other shouted at her and had to remove the truth because the community was informed and she said that the other was wrong, she was wrong with this or that and it is a shame for me and she had to highlight the truth, because the community was informed because of a shout that was made by a gypsy woman.

According to the person quoted above, gossip is all the more important for the Kalderash Roma, as they are part of small communities where the news circulates very fast, especially the bad ones. Being a small community with strong ties between its members, gossip is the equivalent of shame that leads to losing respect in front of other members. 
Being started by women, gossip has two functions. First, it functions as a local newsletter, informing the community of a problem in the community. In this case, gossip practically triggers Kris's procedures because the information needs to be proven, and Kris is the most appropriate procedure for this. The second function is to discourage deviation from community rules or conflicts because members are afraid of the situation in which they would become the subject of these rumors, which is considered shameful for them.

\section{Conclusion}

As in any traditional community, the Kalderash have their own way of dealing intracommunity conflicts. As in any traditional community, this is considered a job only for the men. As professionals in this field, we all know that community conflict management is a process that requires all the members to join and design the best resolution, including women and even children. In our case, the Kalderash are able to see beyond the patriarchal nature of the community and empowered the women with a very important role in this mechanism of justice. Even if it's based on mysticism, it should be judged by its role in conflict prevention and conflict resolution. Being able to curse, needed for oaths and being able to stop a trial (the Kris), we can argue that the Roma women have even more power than the men. Also, based on our sources, they can start a conflict through gossip, the women being the ones who are responsible with spreading the news inside the community. In the same time, the Roma judges started to use their charms and role for more efficient negotiations between the parties involved in a conflict.

I think that the Kalderash woman has another important role in the conflict resolution mechanisms used by the community to solve its internal conflicts. She imposes inherited norms and sanctions, maintains discipline in the family, issues specific expectations about the behavior of the children, referring to the formal orientations that were imposed on her when she was a child, organize the household and, most importantly, is responsible for the childcare. In this light, we can conclude that the following Roma generations will see a growth regarding the role of women at least in matters concerning conflict management because today's women will transfer their experiences and knowledge to the younger generation. If 10-20 years ago, the Roma women was not able to be present at the Kris gathering, now she is able to be a judge which is a very big step forward for this traditional community.

\section{References}

1. Achieng, S. A. (2015). The role of women in conflict management: an assessment of Naboisho conservancy in Kenya. MA paper defended at the Institute of Diplomacy and International Studies (IDIS), University of Nairobi.

2. Bangalie, F. (2011). An examination of the role of women in conflict management: Sierra Leone a case study. MA paper defended at the Faculty of Arts, University of Malta. 
3. Grigore, D. (2008). Romanipen "Fundamente ale identității romilor". In Ghe. Turda (Ed.), Monitor cultural-educativ (pp. 72-90). București: Mira.

4. Ragandang, P., \& Ponce, S. (2019). Philippines: the role of bae in resolving conflict and maintaining tribal peace and order. Conflict Studies Quarterly, 27, 59-69.

5. Wright, A., \& Freeman, L. (2002). More Than Victims. The Role of Women in Conflict Prevention. Washington: Woodrow Wilson International Center for Scholars. 